\title{
Mathematical Modelling of Bifacial Dual SIS Solar Cell and Optimization of Tilt Angle
}

\author{
Kaustuv Dasgupta ( $\nabla$ kaustuv.dasgupta@msit.edu.in ) \\ Meghnad Saha Institute of Technology https://orcid.org/0000-0003-1819-4627 \\ Anup Mondal \\ IIEST Shibpur: Indian Institute of Engineering Science and Technology \\ Utpal Gangopadhyay \\ Meghnad Saha Institute of Technology
}

\section{Research Article}

Keywords: SIS solar cell, ZnO, SnO, MATLAB, bifacial, Silicon, tilt-angle

Posted Date: August 24th, 2021

DOl: https://doi.org/10.21203/rs.3.rs-838042/v1

License: (1) This work is licensed under a Creative Commons Attribution 4.0 International License. Read Full License

Version of Record: A version of this preprint was published at Silicon on January 15th, 2022. See the published version at https://doi.org/10.1007/s12633-021-01542-1. 


\title{
Mathematical Modelling of bifacial dual SIS solar cell and optimization of tilt angle
}

\author{
Kaustuv Dasgupta ${ }^{* a, b}$, Anup Mondal ${ }^{\mathrm{c}}$, Utpal Gangopadhyay ${ }^{\mathrm{a}}$ \\ ${ }^{a}$ Centre for Advance Research in Renewable Energy and Sensor Technology,Meghnad Saha institute of \\ Technology, Kolkata-700150, India \\ ${ }^{b}$ Centre for Green Energy and Sensor System, IIEST, Howrah-711103, India \\ ${ }^{c}$ Department ofChemistry, IIEST, Howrah-711103, India
}

\section{*Correspondence to kaustuvdasgupta83@gmail.com}

\begin{abstract}
The major challenge of PV cell design and installation has always been to find the optimum cost per energy and area of installation of solar panels. In densely populated and high-yielding agricultural country like India land acquisition is becoming an issue. Moreover the consisting demand to deduce the cost per energy indulges the worldwide scientists to design more efficient solar cells with low production cost. In developing countries scientists and engineers are trying to find an amicable solution to meet up these problems. In this paper the mathematical modelling of a dual SIS bifacial vertically mounted solar panel has been proposed to mitigate the energy and land area crisis in countries of Indian subcontinent, south Asia and elsewhere. The SIS (Semiconductor-Insulator-Semiconductor) technology was chosen for its extremely low thermal budget and less complicated production procedure. A bifacial solar cell with SIS junction in both sides was modelled. The front surface SIS junction was considered $\mathrm{ZnO}-\mathrm{SiO}_{2}-\mathrm{Si}(\mathrm{p}$-type) while the back surface junction was considered $\mathrm{Si}(\mathrm{p}$ type) $-\mathrm{Al}_{2} \mathrm{O}_{3}-\mathrm{SnO}$. The efficiency for front and back surface was calculated as $5.64 \%$ and $5.58 \%$ respectively. We have further considered the effect of albedo from two different surfaces (soil and concrete) and the efficiencies of front and back surface for these albedo radiations. The angle of installation was optimized for both these effects. Considering both direct and albedo the all-day efficiency was calculated as $22.47 \%$ for a sunny day tropical region.
\end{abstract}

Keywords: SIS solar cell; ZnO; SnO; MATLAB; bifacial; Silicon; tilt-angle

\section{Introduction}

In conventional mono-facial solar cells harvest solar power only through its front surface. The photons of the sun light have been received by one of its surface nearer to the primary p-n junction. In 1980 Luque et al identified the problem of static concentration in case of conventional single sided solar cells. They designed a solar cell with $\mathrm{n}^{+}-\mathrm{p}-\mathrm{n}^{+}$'transistor-like' structure which could operate in double side illuminated condition [1]. Since then there has been a significant improvement of bi facial solar cell technology with consistent effort of scientists worldwide [2]. The main objective of bi facial solar cell was to harvest the solar power that reflects back from the earth surface, known as albedo, through the back surface. The power from this albedo radiation is otherwise lost in one sided solar cell. Russel et al studied the efficiency of solar cell for albedo spectra of different surfaces [3]. The vertical installation of solar panels became popular to expose the solar cell efficiently to both the direct solar radiation as well as the albedo spectra [4,5]. The vertical installation of solar panel cover lesser area and useful for densely populated and high-yielding lands. The vertical or slightly tilted solar panels have been proved to be advantageous for agricultural photovoltaic (agro-voltaic) application [6,7]. In this paper a new bi facial solar cell is proposed for agro-voltaic application in tropical countries where approximately 12 hours of sunlight is available throughout the year. As the sun trajectory is almost perpendicular to earth surface and noon divides the day time mostly equally throughout the year these arrangements are most useful for Indian subcontinent. Both the surfaces are exposed equally if the panel is placed vertically. Horizontal installation of bifacial solar panel alongside the highways of Bangladesh has been reported by Mahmud et al [8]. A newly designed solar cell, already published by the authors [9], is considered for vertically installed bifacial application in agro-voltaic and highway application in this paper. The structure of the solar cell is depicted in Fig.1. 

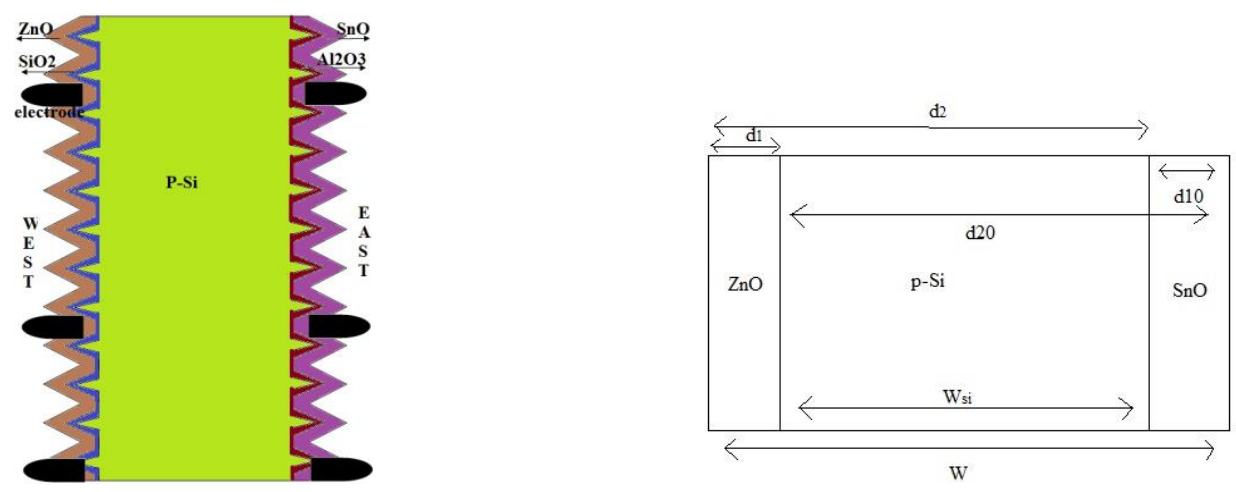

Fig. 1a-1b Structure of dual SIS cell

Instead of conventional silicon homo junction the bifacial structure was considered with SemiconductorInsulator-Semiconductor (SIS) hetero junction for both the surfaces. The proposed panel has to be installed perpendicular to the solar trajectory, that is East-West facing. The East surface is the $\mathrm{Si}(\mathrm{p})-\mathrm{Al}_{2} \mathrm{O}_{3}-\mathrm{SnO}$ junction side was considered as East(E) side while $\mathrm{ZnO}-\mathrm{SiO}_{2}-\mathrm{Si}(\mathrm{p}$-type) was considered to be West side(W). In the first half of the day the $\mathrm{E}$ side is to be illuminated by the direct sunlight and the $\mathrm{W}$ side absorbs the photons from albedo. In the second half the situation gets reversed. The efficiency of both the surfaces was estimated using MATLAB software coding for both direct AM 1.5 sunlight spectra and albedo spectra and hence the all day efficiency was estimated for two different types of earth surface, one for agro-voltaic and another for highway application. The optimum tilt angles for maximum energy output were also calculated from 3-D geometry for both the applications.

The material properties were considered as per the previous work [9] of the authors and tabled in Table 1. The thickness of the Si wafer was considered to be $500 \mu \mathrm{m}$ while the metal oxide semiconductor coatings widths were considered as $100 \mathrm{~nm}(\mathrm{ZnO})$ and $80 \mathrm{~nm}(\mathrm{SnO})$.

Table 1 Material properties considered in the mathematical modelling (at 300K)

\begin{tabular}{|l|c|c|c|}
\hline Parameter & ZnO (n-type) & Si (p-type) & SnO (p ${ }^{+}$-type) \\
\hline Energy band gap $(\mathrm{eV})$ & $\mathrm{E}_{\mathrm{g} 1}=3.37$ & $\mathrm{E}_{\mathrm{g} 2}=1.124$ & $\mathrm{E}_{\mathrm{g} 3}=2.4$ \\
\hline Electron affinity $(\mathrm{eV})$ & $\chi_{1}=4.29$ & $\chi_{2}=4.05$ & $\chi_{3}=3.7$ \\
\hline Effective mass of electron $\left(\mathrm{m}_{0}\right)$ & $m_{n 1}^{*}=0.24$ & $m_{n 2}^{*}=1.08$ & $m_{n 3}^{*}=0.4$ \\
\hline Effective mass of hole $\left(\mathrm{m}_{0}\right)$ & $m_{p 1}^{*}=0.59$ & $m_{p 2}^{*}=0.81$ & $m_{p 3}^{*}=0.9$ \\
\hline Electron mobility $\left(\mathrm{cm}^{2} / \mathrm{V}-\mathrm{s}\right)$ & $\mu_{\mathrm{n} 1}=200$ & $\mu_{\mathrm{n} 2}=1400$ & $\mu_{\mathrm{n} 3}=3$ \\
\hline Hole mobility $\left(\mathrm{cm}^{2} / \mathrm{V}-\mathrm{s}\right)$ & $\mu_{\mathrm{p} 1}=50$ & $\mu_{\mathrm{p} 2}=470$ & $\mu_{\mathrm{p} 2}=7$ \\
\hline Electron lifetime $(\mathrm{s})$ & & $\tau_{\mathrm{n} 2}=29 \times 10^{-6}$ & $\tau_{\mathrm{n} 3}=4 \times 10^{-9}$ \\
\hline Hole lifetime $(\mathrm{s})$ & $\tau_{\mathrm{p} 1}=2.8 \times 10^{-9}$ & $\tau_{\mathrm{p} 2}=10 \times 10^{-6}$ & \\
\hline Electron concentration $\left(\mathrm{cm}^{-3}\right)$ & $\mathrm{N}_{\mathrm{d} 1}=4.8 \times 10^{18}$ & $\mathrm{~N}_{\mathrm{d} 2}=6.7 \times 10^{4}$ & \\
\hline Hole Concentration $\left(\mathrm{cm}^{-3}\right)$ & \multicolumn{2}{|}{$\mathrm{N}_{\mathrm{a} 3}=5 \times 10^{18}$} \\
\hline
\end{tabular}

\section{Calculation of efficiency for direct sunlight spectra (AM 1.5)}

The mathematical modelling of dual SIS junction solar cell was computed with MATLAB software. Donolato's reciprocity theorem for computation of collection probability was applied with appropriate boundary conditions. In the prior study [9] the authors have explained the collection probabilities at both the junction were considered to be unity and the collection probability at the surfaces are determined by surface recombination velocity 400 $\mathrm{cm} / \mathrm{s}$. Hence the collection probability was plotted as depicted in Fig. 2. 


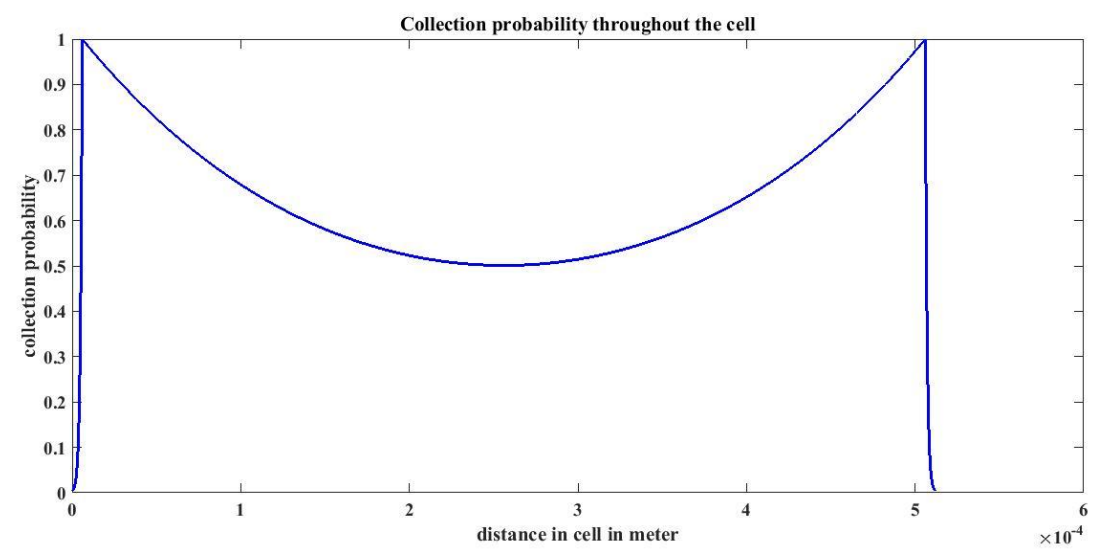

Fig. 2 Collection Probability

Further the light generated current density for $\mathrm{W}$ side (photon received by $\mathrm{ZnO}$ surface) was estimated from the equation 1[9]. Collection probability $\left(\mathrm{C}_{\mathrm{P}}\right)$ in equation 1 was taken as described by Fig. 2 .

$$
\begin{aligned}
J_{L W} & =q\left[\int_{0}^{d_{Z n o}} \int_{\lambda=280 n m}^{370 n m}\left((1-R(\lambda)) \alpha_{Z n o}(\lambda) H_{0}(\lambda) e^{\left(-\alpha_{Z n o} x\right)} d \lambda\right) C_{P}(x) d x\right] \\
& +q\left[\int_{d_{Z n o}}^{d_{2 W}} \int_{\lambda=280 n m}^{370 n m}\left((1-R(\lambda)) \alpha_{S i}(\lambda) H_{0}(\lambda) e^{\left(-\alpha_{Z n o} d_{Z n o}\right)} e^{\left(-\alpha_{S i} x\right)} d \lambda\right) C_{P}(x) d x\right] \\
& +q\left[\int_{d_{Z n}}^{d_{2 W}} \int_{\lambda=370 n m}^{1100 n m}\left((1-R(\lambda)) \alpha_{S i}(\lambda) H_{0}(\lambda) e^{\left(-\alpha_{S i} x\right)} d \lambda\right) C_{P}(x) d x\right] \\
& +q\left[\int_{d_{2 W}}^{D} \int_{\lambda=280 n m}^{370 n m}\left((1-R(\lambda)) \alpha_{S n O}(\lambda) H_{0}(\lambda) e^{\left(-\alpha_{Z n o} d_{Z n o}\right)} e^{\left(-\alpha_{S i} d_{2 W}\right)} e^{\left(-\alpha_{S n o} x\right)} d \lambda\right) C_{P}(x) d x\right] \\
& +q\left[\int_{d_{2 W}}^{D} \int_{\lambda=370 n m}^{460 n m}\left((1-R(\lambda)) \alpha_{S n O}(\lambda) H_{0}(\lambda) e^{\left(-\alpha_{S i} W_{S i}\right)} e^{\left(-\alpha_{S n O} x\right)} d \lambda\right) C_{P}(x) d x\right] \ldots \ldots . .(1)
\end{aligned}
$$

In equation 1, the absorption coefficient of $\mathrm{ZnO}$ and $\mathrm{SnO}$ layers are denoted as $\alpha_{\mathrm{ZnO}}$ and $\alpha_{\mathrm{SnO}}$. The values are considered from empirical formulae as given by Park et al [10] and Liu et al [11] and discussed by Dasgupta et al [9]. The absorption coefficient of Si data was taken from Geen et al [12]. Both the surfaces were considered to be texturized by KOH-IPA alkaline etching resulting micro pyramidal ( 3 micron -5 micron) surface. The reflective indices values over the spectra $R(\lambda)$ were extracted from standard published data [13]. The $H_{0}(\lambda)$ in equation 1 is photon flux for different wavelength of the spectra obtained from AM 1.5 irradiance standard data.

The same arguments were followed to compute the light generated current density for direct 1.5 AM solar radiation received from $\mathrm{E}$ side ( $\mathrm{SnO}$ surface). Equation 1 was edited as the radiation is falling on the opposite side of the cell. 


$$
\begin{aligned}
& J_{L E}=q\left[\int_{0}^{d_{S n o}} \int_{\lambda=280 n m}^{460 n m}\left((1-R(\lambda)) \alpha_{S n o}(\lambda) H_{0}(\lambda) e^{\left(-\alpha_{S n o n} x\right)} d \lambda\right) C_{P}(x) d x\right] \\
& +q\left[\int_{d_{S n o}}^{d_{2 E}} \int_{\lambda=280 n m}^{460 n m}\left((1-R(\lambda)) \alpha_{S i}(\lambda) H_{0}(\lambda) e^{\left(-\alpha_{S \sin } d_{S n o}\right)} e^{\left(-\alpha_{S i x} x\right)} d \lambda\right) C_{P}(x) d x\right] \\
& +q\left[\int_{d_{S n O}}^{d_{2 E}} \int_{\lambda=460 n m}^{1100 m m}\left((1-R(\lambda)) \alpha_{S i}(\lambda) H_{0}(\lambda) e^{\left(-\alpha_{S i} x\right)} d \lambda\right) C_{P}(x) d x\right] \\
& +q\left[\int_{d_{2 E}}^{D} \int_{\lambda=280 n m}^{370 n m}\left((1-R(\lambda)) \alpha_{Z n o}(\lambda) H_{0}(\lambda) e^{\left(-\alpha_{S n o} d_{S n o}\right)} e^{\left(-\alpha_{S i} d_{2 E}\right)} e^{\left(-\alpha_{Z n o} x\right)} d \lambda\right) C_{P}(x) d x\right] \ldots \ldots . . .(2)
\end{aligned}
$$

The wavelength limit in equation 1 and equation 2 were justified from the given value of band gap energy of $\mathrm{ZnO}$ and $\mathrm{SnO}$ (Table 1). The $\mathrm{ZnO}$ layer can absorb the photons with wavelength $370 \mathrm{~nm}$ and lesser. For photons with wavelength more than $370 \mathrm{~nm} \mathrm{ZnO} \mathrm{layer} \mathrm{simply} \mathrm{acts} \mathrm{as} \mathrm{transparent} \mathrm{media.} \mathrm{Similarly} \mathrm{the} \mathrm{SnO} \mathrm{layer}$ becomes transparent for photons with wavelength more than $460 \mathrm{~nm}$ owing the band gap energy of $2.4 \mathrm{ev}$.

The photo generated current for photon flux of different wavelength is shown in Fig. 3.

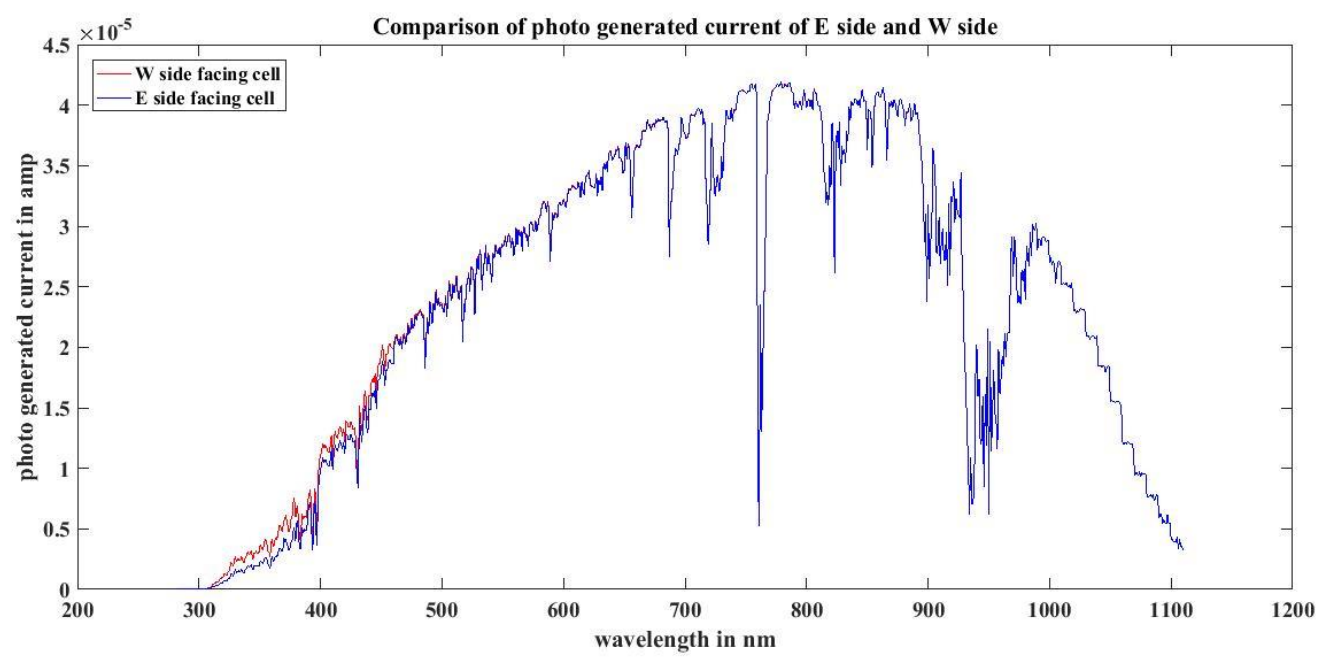

Fig. 3 Photo generated current for different wavelength

In Fig. 3 photo generated current for illumination on East and West side has been plotted together. The graph concludes that there is almost no change in photo generated current for higher wavelength photon flux. This is because both the $\mathrm{ZnO}$ and $\mathrm{SnO}$ layer acts transparent for this region of the spectra. The only change in photogenerated current occurs at the lower range of wavelength owing the different absorption coefficient of $\mathrm{ZnO}$ and $\mathrm{SnO}$.

The dark saturation current density is preliminary a junction property. Thus the dark saturation current density for both the side illumination should be theoretically same. Untila et al also reported the experimental data for SIS hetero junction solar cells which compliment the above statement $[14,15]$. The dark saturation current is expressed as a function of built in potential of the dual SIS solar cell in equation 3 . 


$$
J_{0}=q e^{-q \phi} / k T\left[N_{a 2} \sqrt{\frac{D_{p 1}}{\tau_{p 1}}}+N_{d 3} \sqrt{\frac{D_{n 3}}{\tau_{n 3}}}\right]
$$

Einstein's equation was employed to find out coefficient of diffusion in equation 3 . The built in potential at $\mathrm{ZnO}-\mathrm{Si}$ and $\mathrm{Si}-\mathrm{SnO}$ junctions will be additive to form the overall built in potential $\varphi$ in equation 3 . The total built in potential between $\mathrm{ZnO}$ and $\mathrm{SnO}$ layer of the proposed solar cell structure was computed by adding the built in potential for junction 1 and junction $2, \psi_{1}$ and $\psi_{2}$ respectively.

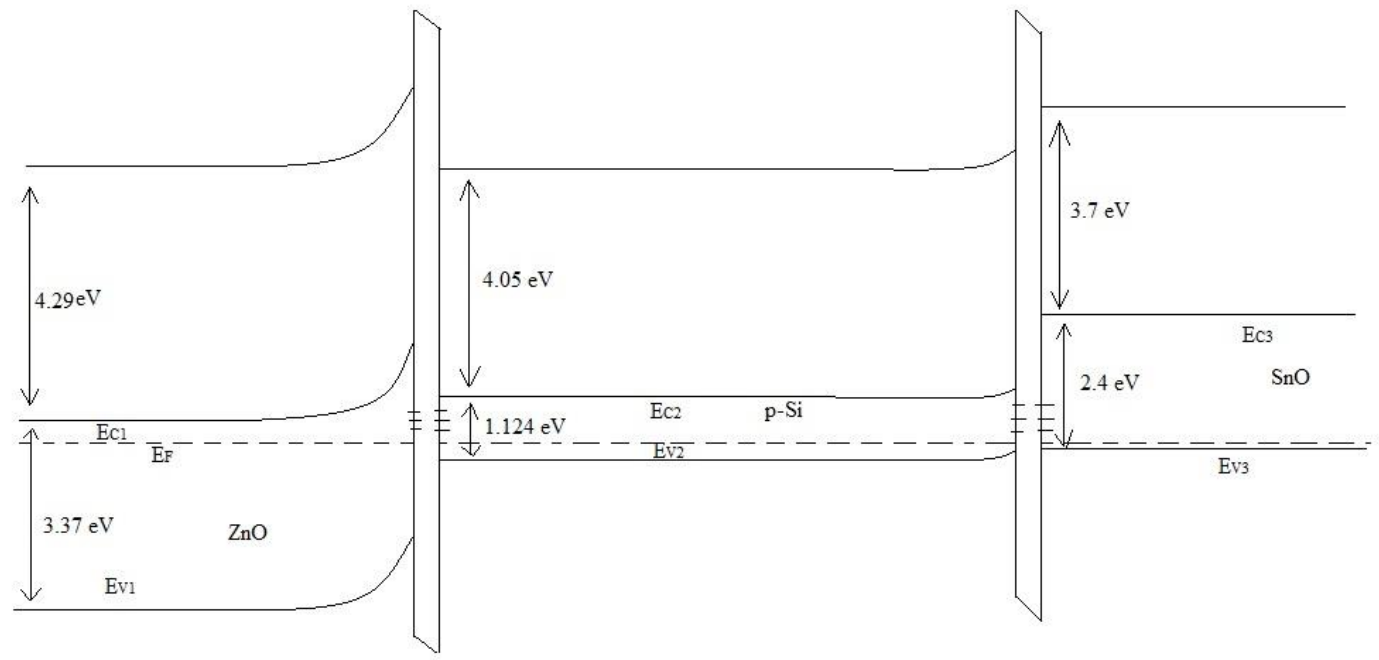

Fig. 4 Energy band diagram of dual SIS structure

The built in potential for both the junctions were estimated from the energy band diagram of the cell as shown in Fig. 4 as expressed in equation 4 and 5 [9].

$$
\begin{aligned}
& \Psi_{1}=\frac{1}{q}\left[\chi_{2}-\chi_{1}+E_{G 2}-k_{B} T \ln \left(\frac{N_{V 2} N_{C 1}}{N_{a 2} N_{d 1}}\right)\right] \ldots \ldots . .(4) \\
& \Psi_{2}=\frac{1}{q}\left[\chi_{3}-\chi_{2}+E_{G 3}-E_{G 2}-k_{B} T \ln \left(\frac{N_{V 3} N_{C 2}}{N_{a 3} N_{d 2}}\right)\right]
\end{aligned}
$$

All the equations 1-5 were hence considered to generate a MATLAB code to obtain the V-I characteristics for both the E-side and $\mathrm{W}$-side facing cell as proposed earlier in this literature. 


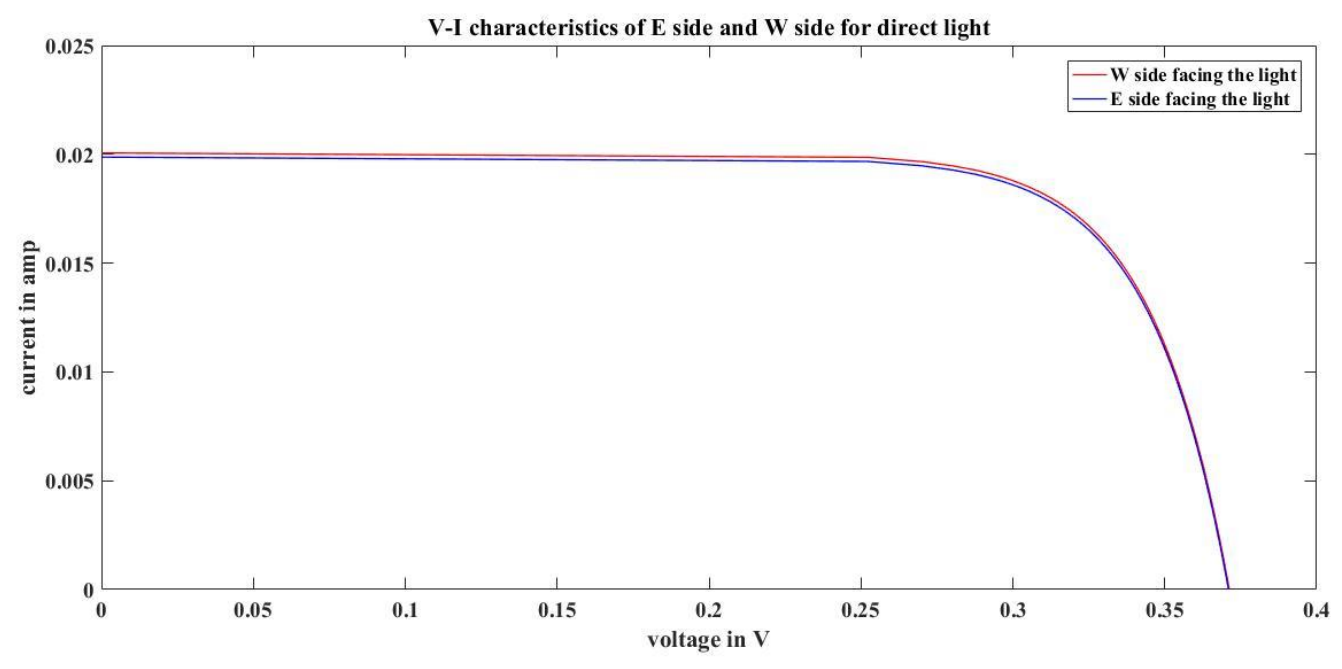

Fig. 5 V-I characteristics of E-side and W-side facing bifacial solar cell

From the V-I characteristics as shown in Fig.5 the solar cell parameters were extracted to compute the efficiency. The obtained parameters for both the sides facing the direct solar radiation are listed in Table 2.

Table 2 Comparison between dual and single SIS solar cell

\begin{tabular}{|l|l|l|l|l|}
\hline & $\mathrm{J}_{\mathrm{SC}}$ in $\mathrm{mA} / \mathrm{cm}^{2}$ & $\mathrm{~V}_{\mathrm{OC}}$ in volt & Form Factor (FF) & \% Efficiency $(\eta)$ \\
\hline $\begin{array}{l}\mathrm{W} \text {-side facing the } \\
\text { sunlight }\end{array}$ & 0.0201 & 0.3712 & 0.7582 & 5.6474 \\
\hline $\begin{array}{l}\text { E-side facing the } \\
\text { sunlight }\end{array}$ & 0.0199 & 0.3712 & 0.7581 & 5.5893 \\
\hline
\end{tabular}

From Table 2 it can be realised that performance parameters for both the sides facing direct sunlight is almost same. Both the junctions are considered to be formed by SIS junctions of materials ( $\mathrm{ZnO}$ and $\mathrm{SnO}$ ) with similar physical properties (Table 1). This results the efficiencies of both sides are nearer to each other. The computed efficiency is nearly same as the experimental value of ZnO-Si SIS solar cell as reported by Untila et al [14] $5.4 \%$. Experimental results reported by other groups of scientists also compliment the computational value of this literature $[16,17]$.

\section{Calculation of efficiency for albedo spectra}

Three different earth surfaces were considered for albedo spectra. The proposed cell was designed for tropical south Asian countries. The soil of Indian sub continental river basins is predominantly alluvium type [18]. In the first case, earth surface was thus considered as alluvium soil. The soil of this area being highly fertile most of the time is covered with green vegetation. Common grass can be approximated to radiate equivalent albedo as same for various common crops in south Asia like paddy, wheat and sugar cane. Thus in the second case the albedo radiation from grass was considered. Lastly in the third case, the bifacial dual SIS solar cell was considered to be installed alongside the highways. For this case albedo radiation from road and pavements were considered. The data of albedo reflection $[19,20]$ were applied in AM 1.5 spectral distribution of solar radiation to get the spectral distribution of albedo radiation of these three conditions mentioned above. 


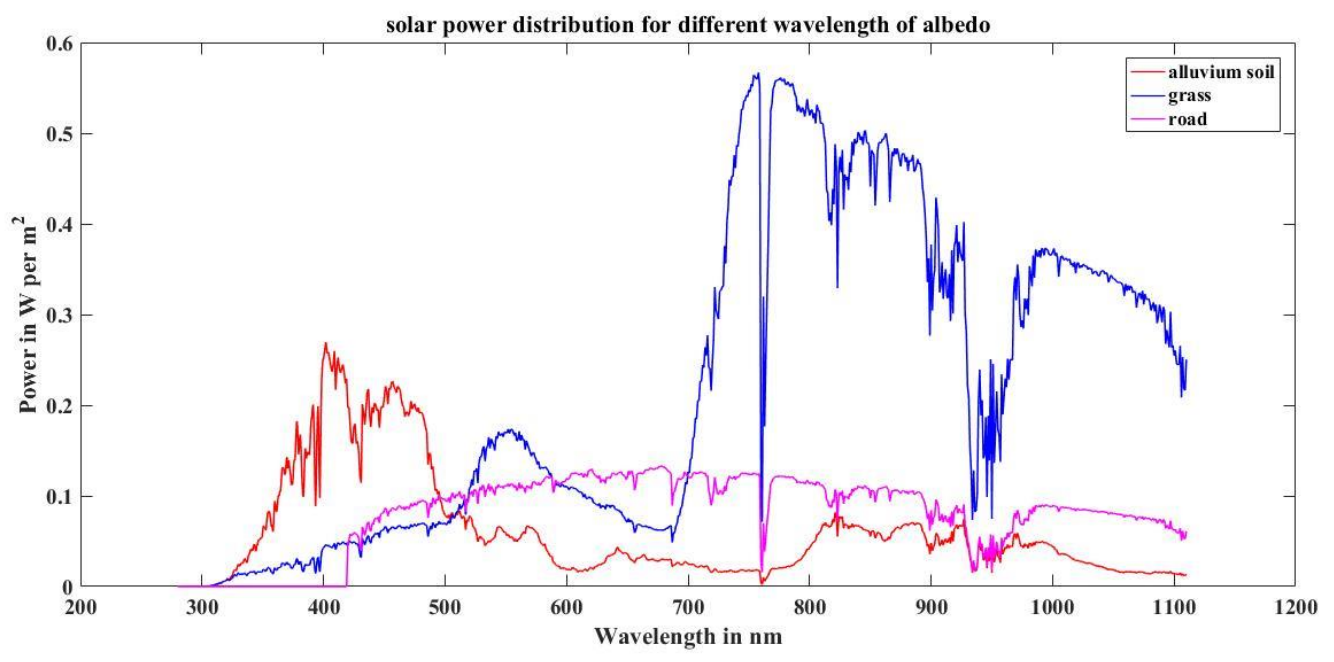

Fig. 6 solar power distribution for different wavelength of albedo from (a) Alluvium soil (b) grass (c) road

Solar power distributions over the spectra for different albedo radiation for alluvium soil, grass and road have been plotted in Fig. 6. Instead of total electro-magnetic wave spectra we have limited our consideration from $280 \mathrm{~nm}$ to $1110 \mathrm{~nm}$ wavelength range. Wavelength above $1100 \mathrm{~nm}$ cannot be absorbed by the material used in this solar cell. Silicon, $\mathrm{ZnO}$ and $\mathrm{SnO}$ practically act as transparent media for higher infrared radiation. Only the effective solar power from albedo radiation was computed from Fig. 6. After integrating the solar power from Fig. 6 the effective albedo solar power was calculated for alluvium soil $\left(49.9367 \mathrm{~W} / \mathrm{m}^{2}\right)$, grass $\left(181.2798 \mathrm{~W} / \mathrm{m}^{2}\right)$ and road $\left(66.274 \mathrm{~W} / \mathrm{m}^{2}\right)$. Further light generated current estimated following equation 1 and 2 for $\mathrm{W}$ and $\mathrm{E}$ surface respectively. $\mathrm{H}_{\mathrm{o}}(\lambda)$ was replaced by $\mathrm{H}^{\prime}(\lambda)$ in equation 1 and 2 in this process. Where $\mathrm{H}^{\prime}(\lambda)$ is the photon flux as a function of wavelength for albedo radiation. $\mathrm{H}^{\prime}(\lambda)$ were available for all the three reflecting surfaces from Fig. 6. The dark saturation current were considered as same as described in the earlier section. Hence V-I characteristics were obtained for both $\mathrm{E}$ and $\mathrm{W}$ sides considering albedo radiation from three different earth surfaces.

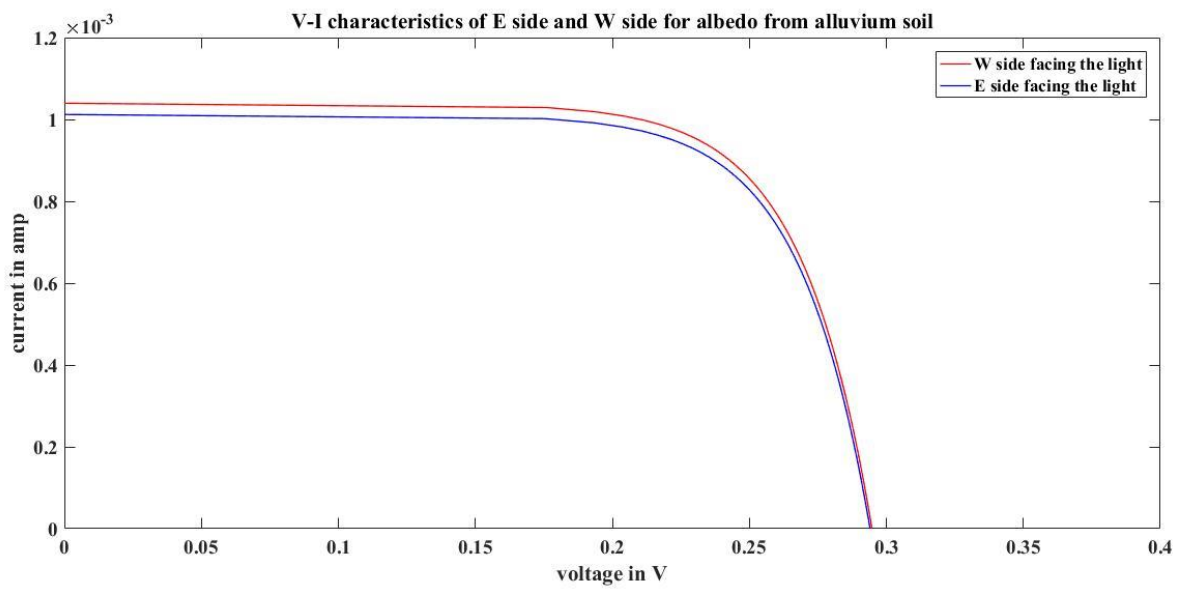



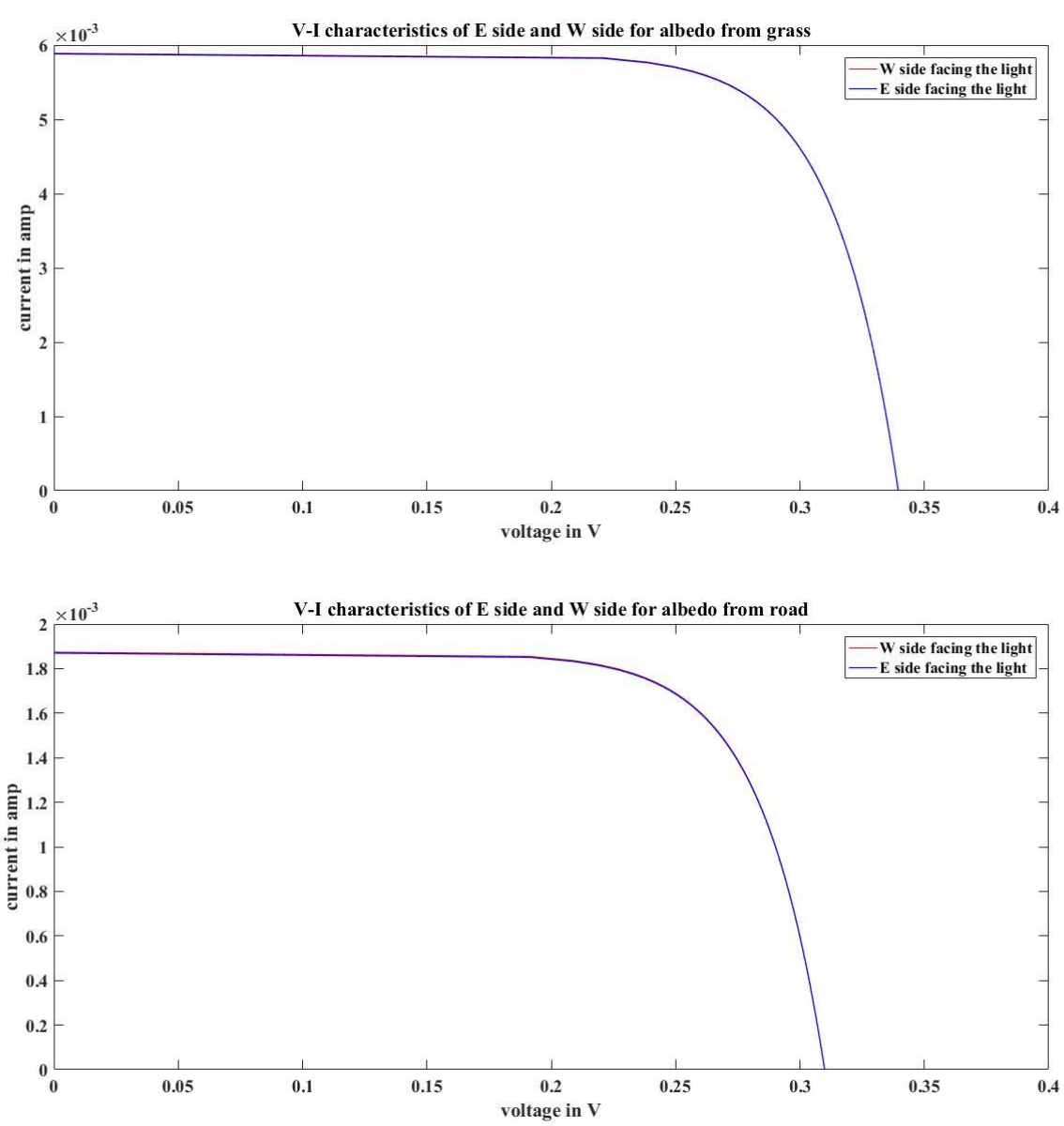

Fig. 7 (a)-7(c) VI characteristics for E/W side solar cell for (a) alluvium soil, (b) grass and (c) road albedo

Fig. 7 is depicting the V-I characteristics for both E/W side facing the different albedo conditions. Different performance parameters of the solar cell for both the surfaces were extracted from these V-I characteristics.

Table 3 Solar cell parameters for different albedo

\begin{tabular}{|c|c|c|c|c|}
\hline $\begin{array}{l}\text { Earth surface } \\
\text { radiating albedo }\end{array}$ & $\begin{array}{l}\text { Total effective } \\
\text { power for proposed } \\
\text { cell in } \mathrm{W} / \mathrm{m}^{2}\end{array}$ & $\begin{array}{ll}\text { Solar } & \text { cell } \\
\text { parameters }\end{array}$ & $\begin{array}{l}\text { East side (light } \\
\text { absorbed from SnO } \\
\text { layer) }\end{array}$ & $\begin{array}{l}\text { West side (light } \\
\text { absorbed from } \mathrm{ZnO} \\
\text { layer) }\end{array}$ \\
\hline \multirow[t]{4}{*}{ Alluvium soil } & \multirow{4}{*}{$H_{\text {alluvium }}^{\prime}=49.9367$} & $\mathrm{~J}_{\mathrm{SC}}$ & 0.0011 Amp & $0.0012 \mathrm{Amp}$ \\
\hline & & $\mathrm{V}_{\mathrm{OC}}$ & $0.2947 \mathrm{~V}$ & $0.2947 \mathrm{~V}$ \\
\hline & & F.F & 0.7179 & 0.7183 \\
\hline & & $\begin{array}{l}\text { Effective efficiency } \\
\left(\eta_{\text {alluvium }}^{\prime}\right)\end{array}$ & $4.2787 \%$ & $4.4077 \%$ \\
\hline \multirow[t]{4}{*}{ Grass } & \multirow{4}{*}{$H_{\text {grass }}^{\prime}=181.2798$} & $\mathrm{~J}_{\mathrm{SC}}$ & 0.0059 Amp & 0.0059 Amp \\
\hline & & $\mathrm{V}_{\mathrm{OC}}$ & $0.3395 \mathrm{~V}$ & $0.3396 \mathrm{~V}$ \\
\hline & & F.F & 0.7430 & 0.7432 \\
\hline & & $\begin{array}{l}\text { Effective efficiency } \\
\left(\eta_{\text {grass }}^{\prime}\right)\end{array}$ & $8.8174 \%$ & $8.2005 \%$ \\
\hline \multirow[t]{4}{*}{ Road } & \multirow{4}{*}{$H_{\text {road }}^{\prime}=66.274$} & $\mathrm{~J}_{\mathrm{SC}}$ & 0.0019 Amp & 0.0019 Amp \\
\hline & & $\mathrm{V}_{\mathrm{OC}}$ & $0.3099 \mathrm{~V}$ & $0.3100 \mathrm{~V}$ \\
\hline & & F.F & 0.7273 & 0.7274 \\
\hline & & $\begin{array}{l}\text { Effective efficiency } \\
\left(\eta_{\text {road }}^{\prime}\right)\end{array}$ & $6.3596 \%$ & $6.3752 \%$ \\
\hline
\end{tabular}

It is to be noted that the effective efficiency $\left(\eta^{\prime}\right)$ was calculated considering only albedo power for effective wavelength $(280 \mathrm{~nm}-1110 \mathrm{~nm})$ for the proposed solar cell. Total albedo power for the entire spectra was not 
considered as higher frequency photons do not get absorbed by none of the material used in fabrication. In later section of this literature, while calculating the all day efficiency, total effective power $\left(\mathrm{H}^{\prime}\right)$ was considered. Hence the total albedo output power was found by multiplying the total effective albedo input power with effective efficiency.

\section{Calculation of all day efficiency}

To understand the advantage of bifacial solar cell while photon is being absorbed by both the surfaces a concept of all day efficiency was adopted. The all day efficiency was defined as the ratio of total electrical energy generated by the solar cell to the total incident solar energy throughout a day ( 24 hours). Since the photon flux from both the direct and albedo radiation depends on the zenith angle of the sun with respect to the solar cell, the output electrical power of solar cell will be a function of the zenith angle. Further the output energy due to direct and albedo radiation input depend on the tilt angle of the solar cell with respect to ground [21]. The bifacial solar cell performs differently for two different sides due to its unequal efficiency for east and west sides. Thus tilt angle plays an important role to determine the all day efficiency. In this section first a general expression is derived for the tilt angle which results the optimum all day efficiency. Then the optimum all day efficiency was estimated setting the tilt angle at that derived value. In this discussion some relatable conditions were considered as mentioned below.

1. The bifacial cell was designed for the tropical regions. Thus it was appropriately considered that the daylight is available approximately 12 hours a day throughout the year.

2. The elevation and height of the PV arrays are considered to be negligible with respect to the length of the land from which albedo radiation is reflected on.

3. AM 1.5 spectral radiations were considered throughout the day.

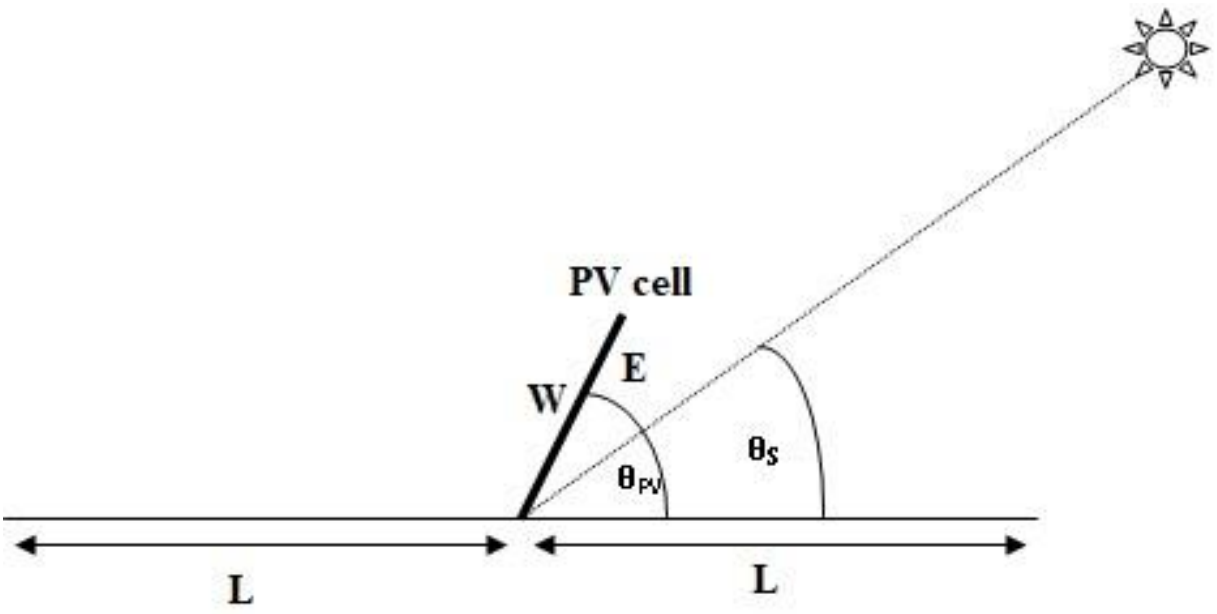

Fig. 8 Schematic diagram of tilted PV bifacial cell and sunlight

The all day efficiency was optimized by fixed tilt angle of the PV cell. The solar tracker was not considered to minimize the cost of installation and maintenance. Fig. 8 is the schematic diagram of the tilted PV cell and sun position to demonstrate the geometry. Table 4 explains significance of the symbols that are used in this discussion.

Table 4 Significance of symbols used

\begin{tabular}{|l|l|}
\hline Symbols & Significance \\
\hline$\theta_{S}$ & $\begin{array}{l}\text { Position angle of the sun for a particular time of day. Defined by zenith angle of the sun } \\
\text { as , } \theta_{S}=\frac{\pi}{2}-\theta_{\text {Zenith }}\end{array}$ \\
\hline
\end{tabular}




\begin{tabular}{|l|l|}
\hline$\theta_{P V}$ & Tilt angle of the PV cell with respect to ground. \\
\hline $\mathrm{L}$ & Length of the land from which albedo radiation was considered. \\
\hline $\mathrm{D}$ & width of the solar cell \\
\hline$\eta_{E}$ & Efficiency of solar cell as photon received from east side (SnO) for direct sunlight \\
\hline$\eta_{W}$ & Efficiency of solar cell as photon received from west side (ZnO) for direct sunlight \\
\hline$\eta_{E}^{\prime}$ & Efficiency of solar cell as photon received from east side (SnO) for albedo \\
\hline$\eta_{W}^{\prime}$ & Efficiency of solar cell as photon received from west side (ZnO) for albedo \\
\hline$H_{0 T}$ & Total solar power per $\mathrm{m}^{2}$ from direct sunlight \\
\hline$H_{T}^{\prime}$ & Total solar power per $\mathrm{m}^{2}$ from albedo sunlight \\
\hline
\end{tabular}

First, the total output energy per $\mathrm{m}^{2}$ for direct sunlight was estimated from the geometry shown in Fig. 8.

$$
\begin{aligned}
E_{\text {direct }} & =\int_{0}^{\theta_{P V}} \eta_{E} H_{0 t} \sin \theta_{P V} \cos \theta_{s} d \theta_{s}+\int_{\theta_{P V}}^{\pi / 2} \eta_{W} H_{0 t} \sin \theta_{P V} \cos \theta_{s} d \theta_{s}-\int_{\pi / 2}^{\pi} \eta_{W} H_{0 t} \sin \theta_{P V} \cos \theta_{s} d \theta_{s} \\
& =H_{0 t} \sin ^{2} \theta_{P V}\left(\eta_{E}-\eta_{W}\right)+2 H_{0 t} \sin \theta_{P V} \eta_{W} \ldots \ldots . .(6)
\end{aligned}
$$

Equation 6 was derived by integrating the normal component of the photon flux falling on the solar cell surface from sunrise to sunset ( $\theta_{\mathrm{s}}$ varies from 0 to $\pi$ ) as solar input. The direct sunlight incidents on $\mathrm{E}$ side for $\theta_{\mathrm{s}}$ varies in between 0 to $\theta_{\mathrm{Pv}}$. The direct sunlight photons are absorbed by $\mathrm{W}$ side when $\theta_{\mathrm{s}}$ changes from $\theta_{\mathrm{Pv}}$ to $\pi$. To estimate the output energy for albedo a length of $\mathrm{L}$ meter in the yard was considered from which the effective radiation falls on the surface of the solar cell. The width of the solar cell was taken as D meter which implies the effective area from which the effective albedo radiation is $\mathrm{LD} \mathrm{m}^{2}$. Following the similar argument and conditions the output energy for albedo was estimated for the entire day time.

$$
\begin{aligned}
E_{\text {albedo }} & =\int_{0}^{\pi / 2}\left(\eta_{E}^{\prime}+\eta_{W}^{\prime}\right) H_{t}^{\prime} L D \sin \theta_{P V} \cos \theta_{s} d \theta_{s}-\int_{\pi / 2}^{\pi}\left(\eta_{E}^{\prime}+\eta_{W}^{\prime}\right) H_{t}^{\prime} L D \sin \theta_{P V} \cos \theta_{s} d \theta_{s} \\
& =2 H_{t}^{\prime} L D \sin \theta_{P V}\left(\eta_{E}^{\prime}+\eta_{W}^{\prime}\right) \ldots \ldots . .(7)
\end{aligned}
$$

The albedo consistently falls on both the $\mathrm{E}$ and $\mathrm{W}$ throughout the day. The normal photon flux on the tilted surfaces was considered from the reflected albedo. From equation 6 and 7 total output energy was estimated as expressed in equation 8 .

$$
E_{\text {output }}=H_{0 t} \sin ^{2} \theta_{P V}\left(\eta_{E}-\eta_{W}\right)+2 \sin \theta_{P V}\left(H_{0 t} \eta_{W}+H_{t}^{\prime} L D \eta_{E}^{\prime}+H_{t}^{\prime} L D \eta_{W}^{\prime}\right) .
$$

To optimize the total output energy with respect to tilt angle, the derivative of output energy with respect to tilt angle was equated to zero. 
$\frac{d E_{\text {output }}}{d \theta_{P V}}=0$

From equation 8 and 9 the condition for optimum tilt angle was established.

$\tan \theta_{P V \max }=\frac{H_{0 t} \eta_{W}+\left(\eta_{E}^{\prime}+\eta_{W}^{\prime}\right) H_{t}^{\prime} L D}{H_{0 t}\left(\eta_{W}-\eta_{E}\right)}$

The tilt angle of the PV cell was considered to be $\theta_{\mathrm{PV} \max }$ and all day efficiency was calculated for different albedo as discussed in section 3 from following expression.

$\eta_{\text {allday }}=\frac{E_{\text {output }}}{E_{\text {input }}}=\frac{H_{0 t} \sin ^{2} \theta_{P V \max }\left(\eta_{E}-\eta_{W}\right)+2 \sin \theta_{P V \max }\left(H_{0 t} \eta_{W}+H_{t}^{\prime} L D \eta_{E}^{\prime}+H_{t}^{\prime} L D \eta_{W}^{\prime}\right)}{\pi H_{0 t}}$.

Further the all-day efficiency was estimated for the optimum tilt angle of proposed solar cell for different albedo using equation 10 and 11. The improvement of all-day efficiency using vertical tilted angle fixed bifacial dual SIS solar cell over monofacial single SIS solar cell was demonstrated. Monofacial solar cell was considered to be installed horizontally without any solar tracker as shown in the Fig. 9.

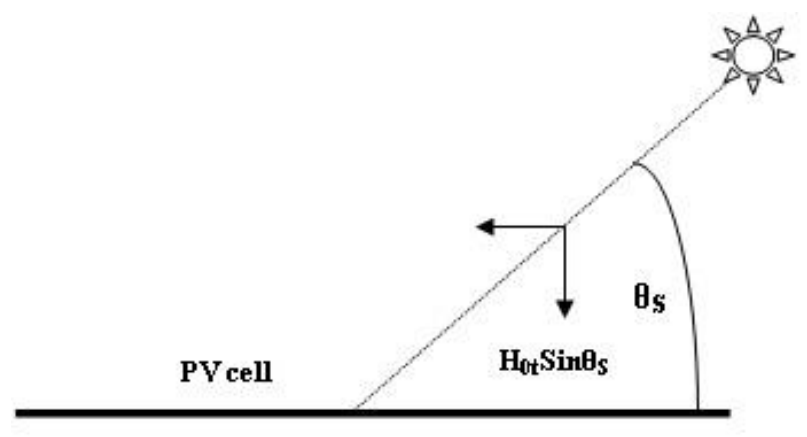

Fig. 9 Schematic diagram of tilted PV monofacial cell and sunlight

The total output energy and all-day efficiency for monofacial horizontally placed was estimated from Fig. 9.

$$
\begin{aligned}
E_{\text {outputmono }} & =\int_{0}^{\pi} \eta_{W} H_{0 t} \sin \theta_{s} d \theta_{s} \\
& =2 \eta_{W} H_{0 t} \ldots \ldots . .(12) \\
\eta_{\text {alldaymono }} & =\frac{2 \eta_{W}}{\pi} \ldots \ldots . .(13)
\end{aligned}
$$


Equation 11 and 13 were compared to establish the improvement of bifacial solar cell over monofacial one. The results for different albedo surfaces were listed in Table 5. The value of $\mathrm{D}$ is $1 \mathrm{~m}$ and the $\mathrm{L}$ is taken as $10 \mathrm{~m}$. The all day efficiency of monofacial SIS cell was estimated as 3.61\% and the produced energy per day per square meter is $0.443 \mathrm{kWh}$.

Table 5 Estimated results for different albedo

\begin{tabular}{|l|l|l|l|c|}
\hline Albedo source & $\theta_{\mathrm{PV} \max }$ & $\eta_{\text {allday }}$ & $\begin{array}{r}\text { Effective all-day } \\
\text { efficiency per side }\end{array}$ & $\begin{array}{c}\text { Produced energy per } \\
\text { meter }^{2} \text { in a day in } \mathrm{kWh}\end{array}$ \\
\hline Alluvium soil & $89.66^{\circ}$ & $6.35 \%$ & $3.17 \%$ & 0.762 \\
\hline Grass & $89.90^{\circ}$ & $22.47 \%$ & $11.23 \%$ & 2.696 \\
\hline Road & $89.76^{\circ}$ & $8.95 \%$ & $4.47 \%$ & 1.074 \\
\hline
\end{tabular}

It is to be noted that bifacial solar cell traps the photon from both the side. Effectively photons incident on both the surfaces were utilized to get the photo-generated current hence the effective all-day efficiency is the cumulative effect of efficiencies per side. It is also to be noted the input energy in each case was considered only the energy from direct light and not the albedo. It is more rational to compare the energy produced by the cell per day per square meter. In Table 5 it can be observed that there is a significant ( $\sim 50 \%$ for alluvium soil) enhancement in energy production in bifacial solar cell over mono-facial one.

\section{Conclusion}

The mathematical model of this article shows a significant enhancement in energy efficiency for agricultural and highway applications in tropical countries like India. The bifacial vertically installed solar cells required less area for installation. The junctions were created by semiconductor metal oxides layers. The advanced thin film technology can be applied to form those junctions with extremely low thermal budget and manufacturing cost. This bifacial dual SIS solar cell could be a viable solution for agricultural and rural power supply in developing countries. The simulation results were verified by the experimental results [22] where it was reported that a $50 \%$ enhancement. It was also investigated that albedo from the crop land during harvesting seasons is most effective for PV power generation. Results from Table 5 shows a green field filled with grass or other green vegetation is more beneficial that dry land (alluvium soil). This is also an important observation for multi harvesting high 
yielding lands of India and Bangladesh. This type of solar cells could be highly recommended for these areas.

The same model is applicable for other types of bifacial solar cells to approximate the optimum tilt angle.

\section{Declaration}

Funding: No institutional funding was used

\section{Conflicts of interest/Competing interests: Not any}

Availability of data and material: Available with authors.

Code availability: Available with authors.

\section{Authors' contributions:}

Kaustuv Dasgupta: Writing the manuscript, Theoretical analysis, Coding, Result Analysis

Anup Mondal: Supervising, data correction

Utpal Gangopadhyay: Ideation, Supervising, Data analysis

Compliance with ethical standards: The study was not funded by any funding organization. MATLAB software used in the study is licensed under Meghnad Saha Institute of Technology. The authors declare that they have no conflicts of interest. This article does not contain any studies involving animals performed by any of the authors. This article does not contain any studies involving human participants performed by any of the authors.

Consent to participate: This article does not contain any studies involving human participants performed by any of the authors.

Consent for Publication: We give our consent for the publication of identifiable details, which can include photograph(s) and/or videos and/or case history and/or details within the text ("Material") to be published in the Silicon, Springer. Therefore, anyone can read material published in the Journal. 
Acknowledgments: We acknowledge Meghnad Saha Institute of Technology for providing us with MATLAB

software for simulation.

\section{Reference}

[1] A. Luque, A. Cuevas, J.M. Ruiz, Double-sided n+-p-n+ solar cell for bifacial concentration, Solar Cells, Volume 2, Issue 2, 1980, Pages 151-166

[2] R. Guerrero-Lemus, R. Vega, Taehyeon Kim, Amy Kimm, L.E. Shephard, Bifacial solar photovoltaics - A technology review, Renewable and Sustainable Energy Reviews, Volume 60, 2016, Pages 1533-1549

[3] T. C. R. Russell, R. Saive, A. Augusto, S. G. Bowden and H. A. Atwater, "The Influence of Spectral Albedo on Bifacial Solar Cells: A Theoretical and Experimental Study," in IEEE Journal of Photovoltaics, vol. 7, no. 6, pp. 1611-1618, Nov. 2017

[4] Hezel, R. (2003), Novel applications of bifacial solar cells. Prog. Photovolt: Res. Appl., 11: 549-556.

[5] V Poulek, M Libra, A very simple solar tracker for space and terrestrial applications, Solar Energy Materials and Solar Cells, Volume 60, Issue 2, 2000, Pages 99-103

[6] M. H. Riaz, H. Imran and N. Z. Butt, "Optimization of PV Array Density for Fixed Tilt Bifacial Solar Panels for Efficient Agrivoltaic Systems," 2020 47th IEEE Photovoltaic Specialists Conference (PVSC), 2020, pp. $1349-1352$

[7] M. H. Riaz, H. Imran, R. Younas, M. A. Alam and N. Z. Butt, "Module Technology for Agrivoltaics: Vertical Bifacial Versus Tilted Monofacial Farms," in IEEE Journal of Photovoltaics, vol. 11, no. 2, pp. 469477, March 2021

[8] M. S. Mahmud et al., "Solar Highway in Bangladesh Using Bifacial PV," 2018 IEEE International Conference on System, Computation, Automation and Networking (ICSCA), 2018, pp. 1-7

[9] Dasgupta, K., Mondal, A., Ray, S. et al. Mathematical Modelling of a Novel Hetero-junction Dual SIS ZnOSi-SnO Solar Cell. Silicon (2021).

[10] Park, K. C., Ma, D. Y., \& Kim, K. H. (1997). The physical properties of Al-doped zinc oxide films prepared by RF magnetron sputtering. Thin Solid Films, 305(1-2), 201-209.

[11] Liu, Q.-J., Liu, Z.-T., \& Feng, L.-P. (2010). First-principles calculations of structural, electronic and optical properties of tetragonal SnO2 and SnO. Computational Materials Science, 47(4), 1016-1022.

[12] Green, M.A. and Keevers, M.J. (1995), Optical properties of intrinsic silicon at 300 K. Prog. Photovolt: Res. Appl., 3: 189-192.

[13] D. Muñoz, P. Carreras, J. Escarré, D. Ibarz, S. Martín de Nicolás, C. Voz, J.M. Asensi, J. Bertomeu, Optimization of $\mathrm{KOH}$ etching process to obtain textured substrates suitable for heterojunction solar cells fabricated by HWCVD, Thin Solid Films, Volume 517, Issue 12, 2009, Pages 3578-3580

[14] G.G. Untila, T.N. Kost, A.B. Chebotareva, Bifacial 8.3\%/5.4\% front/rear efficiency ZnO:Al/n-Si heterojunction solar cell produced by spray pyrolysis, Solar Energy, Volume 127, 2016, Pages 184-197

[15] G.G. Untila, T.N. Kost, A.B. Chebotareva, ITO/SiOx/n-Si heterojunction solar cell with bifacial $16.6 \% / 14.6 \%$ front/rear efficiency produced by ultrasonic spray pyrolysis: Effect of conditions of SiOx growth by wet-chemical oxidation, Solar Energy, Volume 204, 2020

[16] Karin Keis, Eva Magnusson, Henrik Lindström, Sten-Eric Lindquist, Anders Hagfeldt, A 5\% efficient photoelectrochemical solar cell based on nanostructured $\mathrm{ZnO}$ electrodes, Solar Energy Materials and Solar Cells, Volume 73, Issue 1, 2002, Pages 51-58 
[17] Afify H. H., EL-Hefnawi S. H., Eliwa A. Y., Abdel-Naby M. M. and Ahmed N. M. , Realization and Characterization of ZnO/n-Si Solar Cells by Spray Pyrolysis , EJS, 2005, 28, 243-254

[18] M.S. Sirsat, E. Cernadas, M. Fernández-Delgado, R. Khan, Classification of agricultural soil parameters in India, Computers and Electronics in Agriculture, Volume 135, 2017, Pages 269-279

[19] Meerdink, S. K., Hook, S. J., Roberts, D. A., \& Abbott, E. A. (2019). The ECOSTRESS spectral library version 1.0. Remote Sensing of Environment, 230(111196), 1-8.

[20] Baldridge, A. M., S.J. Hook, C.I. Grove and G. Rivera, 2009.. The ASTER Spectral Library Version 2.0. Remote Sensing of Environment, vol 113, pp. 711-715.

[21] M. Tahir Patel, M. Ryyan Khan, Xingshu Sun, Muhammad A. Alam, A worldwide cost-based design and optimization of tilted bifacial solar farms, Applied Energy, Volume 247, 2019, Pages 467-479

[22] L. Kreinin, N. Bordin, A. Karsenty, A. Drori, N. Eisenberg, Bifacial, Monitoring, Photovoltaic (PV) Module, Silicon Solar Cell(s), 26th European Photovoltaic Solar Energy Conference and Exhibition,2011, Pages: $3140-3143$. 